\title{
The Role of Forensic Accounting in Discovering Financial Fraud
}

\section{Hamdan MW*}

Department of Accounting, Faculty of Finance and Administration, University of Philadelphia, Jordan

\begin{abstract}
The objective of this research is to study the effect of forensic accounting on discovering and mitigate fraud. Questionnaire was used as a tool to collect data. The questionnaire composed of two parts. The first part was concerned with collecting information about forensic accounting requirements and the second part was concerned with collecting information about the role of forensic accounting in discovering fraud. Confirmatory factor analysis was used as a tool to figure out the contribution of different items to forensic accounting variables and its contribution in discovering fraud. The results showed that forensic accounting is an effective tool to find fraud if the general requirements were available to prepare professional forensic accountants.
\end{abstract}

Keywords: Forensic accounting; Fraud; Discovering

\section{Introduction}

Legal work requires support by different other scientific fields to support legal decisions. One of these supportive specialties in legal work is the forensic accounting [1]. Forensic accounting defined as that niche used to disclose any financial or accounting violations [2]. The skills required practicing forensic accounting and to influence positively is high and crucial. This branch of accounting is not only concerned with practicing the accounting jobs, but also to use the accumulative experiences and skills to test matters related to law in civil, criminal and jurisprudence. Accordingly, the charisma of forensic accountant is different in all considerations and to make it helpful it was taught as a separate branch of accounting [3].

Forensic accounting depends on different pillars. These pillars include the character of accountant, experience and tools required, and the knowledge of law. The character of accountant, is concerned the experience of the accountant, independency, creativity, and investigation capabilities. Hopwood et al. (2008) reported that forensic accounting requires investigative and analytical skills [4]. On the other hand, Rasmussen and Leauance (2004) used 'investigative accounting' as alternative idiom for forensic accounting [5]. The analytical skills required, as the forensic accountant need to go through financial reports and other accounting documents. Moreover, he needs to go through transactions and their validity. The accountant needs to search and analyze the origin of different numbers. In this regard, the forensic accountants need to have the basic accounting skills. These skills also included the professionalism of the language of business.

Level of education is one of the personal traits that determine the professionalism of forensic accountant. The performances of the forensic accountant depend on the level of educational experience gained. Undergraduate levels of accounting will not find high demand to practice the forensic accounting compared to undergraduate levels. Graduate education levels will high demand compared to other levels [6]. Moreover, the level of education is not enough the auditing experience is very important to integrate the educational experience [7].

Writing communication skills considered another skills should owned by the forensic accountant. In such business, writing is the final tool used to communicate the court and report different cases in law branches. Professional writing skills will facilitate proper connections with different parties in concern [8]. In the same field, the verbal communication skills are also very important in executing the forensic accounting. Verbal communication skills will help the accountant to meet and communicate companies' staff involved in fraud [9]. Moreover, the forensic accounting may call for witnesses in cases that its success will depend on his capabilities in verbal communication [10].

Many other skills required by forensic accountant whiling executing his work. Of these skills, the analytical skills [8]. The analytical skills of forensic accountant are very important to execute the required analysis and to reserve the secrecy of collected evidences. This skill should be accompanies with computer skills as a tool to use the analytical skills [11].

Consequently, the forensic accountant should have deep and good investigation skills to be able to build skepticism and collect the required evidence to assure or cancel. These skills cannot be built unless the accountant gained a good background in law [12]. Such experience will facilitate the forensic account to diagnose any violations in formal funded programs [13].

Fraud and Fraudulent cases in some countries increased the demand for forensic accounting [1]. Fraud included wide varies of practices out of law to possess or change the existed financial conditions for the benefit of third party [14]. The accounting skills used by forgers to hold fraud are very high to be discovered. Also, the forger used to hide to change original figures to accomplish new state meets his needs. This leads to a situation that requires from forensic accountant to have high skills. This explains the high degree of professionalism required to execute forensic accounting [1]. Deeper investigation required to reach the facts.

Discovering fraud requires the deal with smart forgers to find the evidences needed to approve the fraud cases. High forensic accounting skills will make it possible to discover most of the fraud cases. The authors reported that any high expert accountant can be a forensic

${ }^{*}$ Corresponding author: Mohammad W Hamdan, Department of Accounting Faculty of Finance and Administration, University of Philadelphia, Jordan, Tel: 00962795558875; E-mail: hamdan.papers@gmail.com

Received May 02, 2018; Accepted July 10, 2018; Published July 17, 2018

Citation: Hamdan MW (2018) The Role of Forensic Accounting in Discovering Financial Fraud. Int J Account Res 6: 176. doi:10.35248/2472-114X.18.6.176

Copyright: (c) 2018 Hamdan MW. This is an open-access article distributed under the terms of the Creative Commons Attribution License, which permits unrestricted use, distribution, and reproduction in any medium, provided the original author and source are credited. 
Citation: Hamdan MW (2018) The Role of Forensic Accounting in Discovering Financial Fraud. Int J Account Res 6: 176. doi: 10.35248/2472-

accountant. Still this is not a role unless the professional accountant has all the required skills to execute and manage all processes to discover fraud [15-20].

\section{Methodology}

Forensic accounting has been used as a tool to support juridical and law experience in the financial and accounting fields. The role of forensic accountant is to use his accumulative experiences in accounting, accounting tools and legal knowledge to help in reporting any violations, or to discover. The objective of this paper is to test the effect of forensic accounting on discovering financial fraud according to accountants' point of view. Questionnaire used as a tool to collect data. The questionnaire composed of three parts. The first part concerned with collecting data about the demographic characteristics of respondents, while the second part donated to collected about the skills of forensic accounting, tools and procedures used in forensic accounting, legal knowledge and the fields of forensic accounting. The third part concerned to measure the extent of discovering fraud using the forensic accounting. Five Likert scale was used to measure the trends of sample for the different items [21-23].

To validate the questionnaire, pilot survey used. Pilot sample includes 20 accountants. Data reliability and validation were measured. The result of reliability test is shown in Table 1 .

Simple random sample of 630 accountants were selected randomly

\begin{tabular}{|l|c|}
\hline \multicolumn{1}{|c|}{ Variable } & Cronbach's Alpha \\
\hline Forensic accounting skills & 0.93 \\
\hline Knowledge of procedures & 0.95 \\
\hline Legal background & 0.86 \\
\hline Knowledge of forensic accounting & 0.93 \\
\hline
\end{tabular}

Table 1: Reliability analysis using Cronbach's Alpha. from the accounting offices. Data of the collected questionnaires were entered to SPSS (Ver. 22) for analysis. Descriptive statistics were used to analyze the demographic characteristics of the sample and the trends for the study variables. Differential statistics including t-test and analysis of variance (ANOVA) were used to test the effect of demographic characteristics on the evaluation of forensic accounting variables, while linear regression was used to test the effect of forensic accounting variables on discovering fraud.

Factor analysis and confirmatory factor analysis were used to figure out the extent the items measure the variables and the extent each variable affect the ability of forensic accounting to mitigate fraud. Normal distribution test was run for the different items to check the possibility of using FA and CFA. The results of the normal distribution test showed that the range of skewness and kurtosis values were within the range -1 to 1 for skewness and -1.5 to 1.5 for kurtosis according to Hair et al. (Table 2).

\section{Results}

The objective of this research was to measure the extent accountants realizing the importance of the variables of forensic accounting and its effect on discovering fraud. Factor analysis was used to measure the extent each item measures the variable. The least threshold for loading factors (0.4) according to Hair et al. (2007).

\section{Factor Analysis}

\section{Forensic accounting skills}

Table 3 shows the sample trends for the forensic accounting skills required for professional forensic accountant. The highest trend was recorded for the deep audit experience with mean 3.45. The second trend was recorded for the basic accounting skills with mean (3.31). Certification for forensic accounting took the third order as request

Basic accounting skills are very important to be a successful forensic accountant (S1)

Certification for forensic accounting is very important to insure capabilities to discover fraud (S2)

Deep experience of financial statement analysis and interpretation is crucial to practice forensic accounting (S3)

Communalities

Experience of fraud detection capabilities is very important to be successful forensic accountant (S4)

Deep audit experience is very important for successful forensic accounting (S5)

Analytical skills are very important to seek the origin of accounts (T1)

Data mining skills are very important (T2)

The language of business is very important skill for forensic accountant. (T3)

Writing communication skills are very important for forensic accountant (T4)

Verbal communication skills are very important for forensic accountant (T5)

Background of criminal law is very important for forensic accountant (B1)

Knowledge of case procedures is important for forensic accounting (B2)

Knowledge of civil procedures and evidence rules is important to handle forensic accounting (B3)

Enforcement of law knowledge is important (B4)

Knowledge of testifying if very important for forensic accounting (B5)

The ability to perform conflict check is very important in conducting forensic accounting (A1)

Running investigations in fraud cases is very important in forensic accounting (A2)

Finding conflict areas and finding evidence is very important in forensic accounting (A3)

Determining responsibilities is very important to approve fraud (A4)

Connecting analysis with other documentation is very important in discovering fraud (A5)

Fraud mitigation depends on practicing forensic accounting as profession (R1)

The use of deep analysis of forensic accounting help in fraud discovering (R2)

Forensic accounting is very crucial to minimize fraud in developing countries (R3)

Practicing forensic accounting a specialty improves fraud management (R4)

Forensic accountants with law background improve the chance to investigate in fraud cases (R5)

\begin{tabular}{|c|c|c|}
\hline Communalities & Loading & KMO \\
\hline 0.672 & 0.820 & 0.847 \\
\hline 0.707 & 0.841 & \\
\hline 0.722 & 0.839 & \\
\hline 0.647 & 0.850 & \\
\hline 0.687 & 0.804 & \\
\hline 0.734 & 0.829 & 0.867 \\
\hline 0.754 & 0.857 & \\
\hline 0.662 & 0.868 & \\
\hline 0.643 & 0.814 & \\
\hline 0.653 & 0.802 & \\
\hline 0.758 & 0.808 & 0.854 \\
\hline 0.781 & 0.871 & \\
\hline 0.607 & 0.884 & \\
\hline 0.651 & 0.779 & \\
\hline 0.746 & 0.807 & \\
\hline 0.790 & 0.864 & \\
\hline 0.768 & 0.889 & \\
\hline 0.716 & 0.876 & \\
\hline 0.750 & 0.846 & \\
\hline 0.643 & 0.866 & \\
\hline 0.669 & 0.802 & 0.872 \\
\hline 0.680 & 0.818 & \\
\hline 0.710 & 0.825 & \\
\hline 0.962 & 0.843 & \\
\hline & 0.832 & \\
\hline
\end{tabular}

Table 2: Factor analysis. 
Citation: Hamdan MW (2018) The Role of Forensic Accounting in Discovering Financial Fraud. Int J Account Res 6: 176. doi: 10.35248/2472114X.18.6.176

to practice forensic accounting (3.22). Negative attitudes recorded for deep experience of fraud detection capabilities with mean (2.9).

Concerning the required tools and procedures needed for forensic accountant, the results showed that the high trend was for writing communication skills with mean 3.61 , followed by verbal communication skills with mean 3.56 (Table 4).

Background of criminal law considered the first priority in the legal knowledge with mean 3.57 to practice the forensic accounting. The second concern was for the knowledge of case procedures followed with mean 3.52. The least attitudes were given for the enforcement of law knowledge with negative attitude (Table 5).

The first priority was given for the investigations capabilities in fraud cases with mean 3.38. The sample considered this capability crucial to practice the forensic accounting. The connection of analysis with different documentation with mean 3.32, followed by determining the responsibility in cases is very important to approve the fraud with
3.27. Finding conflict areas and evidences was in the four ranks with mean 3.25. The least attitude was given for the ability to perform conflict check with mean 3.09 (Table 6).

Deep analysis was reported by the sample as a tool to discover fraud with mean 3.69 , followed by the background of law improves the chance to investigation in fraud cases and finding fraud with mean 3.43. Also, practicing forensic accounting as a specialty will facilitate fraud management with mean 3.41 (Table 7).

\section{Confirmatory factor analysis}

Figure 1 shows the confirmatory factor analysis for the effect of different criteria on discovering fraud using forensic accounting. The first model included 20 dependent items distributed over four variables and five items for the dependent variable related to fraud discovery. The first trial for model without correlation between the independent variables showed that some fitness items were out of range $\mathrm{GFI}<0.90$, $\mathrm{AGFI}<0.9, \mathrm{TLI}=0.81, \mathrm{CFI}=0.828$ and $\mathrm{RMSEA}=0.105$ (Hair et al. 2007).

\begin{tabular}{|l|c|}
\hline Item & Mean \\
\hline Deep audit experience is very important for successful forensic accounting (S5) & 3.45 \\
\hline Basic accounting skills are very important to be a successful forensic accountant (S1) & 3.31 \\
\hline Certification for forensic accounting is very important to insure capabilities to discover fraud (S2) & 3.22 \\
\hline \begin{tabular}{l|l|} 
Deep experience of financial statement analysis and interpretation is crucial to practice forensic \\
accounting (S3)
\end{tabular} & 3.11 \\
\hline Experience of fraud detection capabilities is very important to be successful forensic accountant (S4) & 1.25 \\
\hline Price efficiency increase the profit margin & 1.20 \\
\hline
\end{tabular}

Table 3: Means and st. dev. for the trends of forensic accounting skills.

\section{Item}

Writing communication skills are very important for forensic accountant (T4)

Verbal communication skills are very important for forensic accountant (T5)

Data mining skills are very important (T2)

Analytical skills are very important to seek the origin of accounts (T1)

The language of business is very important skill for forensic accountant. (T3)

\begin{tabular}{|c|c|}
\hline Mean & Std. Dev \\
\hline 3.61 & 1.17 \\
\hline 3.56 & 1.17 \\
\hline 3.55 & 1.17 \\
\hline 3.49 & 1.17 \\
\hline 3.48 & 1.24 \\
\hline
\end{tabular}

Table 4: Means and st. dev of the tools and procedures applied in forensic accounting.

\section{Item}

Background of criminal law is very important for forensic accountant (B1)

Knowledge of case procedures is important for forensic accounting (B2)

Knowledge of testifying if very important for forensic accounting (B5)

Knowledge of civil procedures and evidence rules is important to handle forensic accounting (B3)

Enforcement of law knowledge is important (B4)

\begin{tabular}{|c|c|}
\hline Mean & Std. Dev \\
\hline 3.57 & 1.15 \\
\hline 3.52 & 1.07 \\
\hline 3.46 & 1.09 \\
\hline 3.33 & 1.07 \\
\hline 2.97 & 1.19 \\
\hline
\end{tabular}

Table 5: Means and st. dev of background of legal knowledge.

\section{Item}

Running investigations in fraud cases is very important in forensic accounting (A2)

Connecting analysis with other documentation is very important in discovering fraud (A5)

Determining responsibilities is very important to approve fraud (A4)

Finding conflict areas and finding evidence is very important in forensic accounting (A3)

The ability to perform conflict check is very important in conducting forensic accounting (A1)

\begin{tabular}{|c|c|c|}
\hline & Mean & Std. Dev \\
\hline & 3.38 & 1.15 \\
\hline ) & 3.32 & 1.13 \\
\hline (A1) & 3.27 & 1.14 \\
\hline
\end{tabular}

Table 6: Means and st dev of knowledge of the fields of forensic accounting assignment.

\section{Item}

The use of deep analysis of forensic accounting help in fraud discovering (R2)

Forensic accountants with law background improve the chance to investigate in fraud cases (R5)

Practicing forensic accounting as a specialty improves fraud management (R4)

Fraud mitigation depends on practicing forensic accounting as profession (R1)

Forensic accounting is very crucial to minimize fraud in developing countries (R3)

\begin{tabular}{|c|c|}
\hline Mean & Std. Dev \\
\hline 3.69 & 1.08 \\
\hline 3.43 & 1.21 \\
\hline 3.41 & 1.03 \\
\hline 3.40 & 1.18 \\
\hline 3.29 & 1.19 \\
\hline
\end{tabular}

Table 7: Means and st. dev for the role of discovering fraud. 
Citation: Hamdan MW (2018) The Role of Forensic Accounting in Discovering Financial Fraud. Int J Account Res 6: 176. doi: 10.35248/2472114X.18.6.176

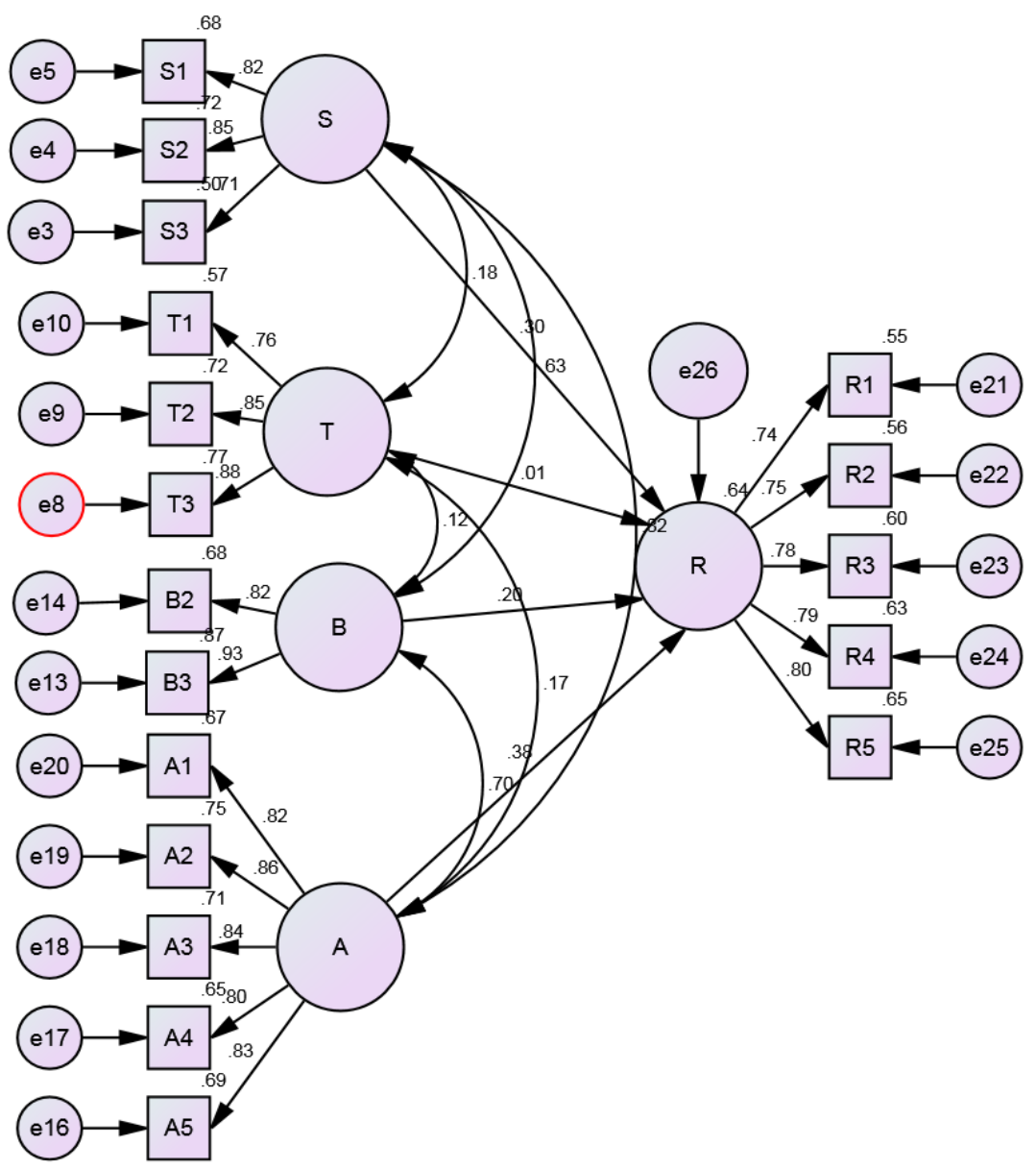

Figure 1: The confirmatory factor analysis for the effect of different criteria on discovering fraud using forensic accounting.

\begin{tabular}{|l|c|c|c|c|c|c|c|c|}
\hline \multicolumn{1}{|c|}{ Model step } & $\mathbf{X}^{2}$ & $\mathbf{d f}$ & $\mathbf{p}$ & GFI & AGFI & TLI & CFI & RMSEA \\
\hline Initial model without correlation & 2167.881 & 271 & 0.001 & 0.791 & 0.750 & 0.810 & 0.828 & 0.105 \\
\hline Model with correlation & 1109.179 & 265 & 0.001 & 0.871 & 0.842 & 0.913 & 0.923 & 0.071 \\
\hline Removed items S4, S5, T4, T5, B1, B4, B5 & 422.41 & 125 & 0.001 & 0.933 & 0.909 & 0.952 & 0.960 & 0.062 \\
\hline
\end{tabular}

Table 8: CFA fitness parameters.

Adding correlation for the independent variable improves the fitness of the model that different fitness measurement became within the acceptable range TLI $>0.9$, CFI $>0.9$ and RMSEA $<0.08$ but still GFI and AGFI were less than 0.9 .

To improve model fitness, the items with low loading facto were removed. The items $\mathrm{S} 4, \mathrm{~S} 5, \mathrm{~T} 4, \mathrm{~T} 5, \mathrm{~B} 1, \mathrm{~B} 4$, and $\mathrm{B} 5$ were removed. The fitness measures became within the required range; $\chi^{2}=422.41, \mathrm{df}=125$, prob. $=0.001$, GFI $=0.933$, AGFI $=0.909$, TLI $=0.952$, CFI $=0.960$, and RMSEA $=0.062$ (Table 8)

Table 9 shows the regression weights for the effect of different variables on fraud discovering. The results showed that there was significant effect of the skills required forensic accounting, background of legal knowledge, and forensic accounting assignments on fraud discovering $(p<0.001)$. The tools and procedures used in forensic accounting did not affect fraud discovering. The results showed that the highest effect was for forensic assignments with loading factor 0.352 , followed by the skills required to practice the forensic accounting
(0.251), and the last loading factor was for background of legal knowledge (0.176). The least not significant loading factor was for the tools and procedures using in forensic accounting.

\section{Discussion}

The high demand on forensic accounting due to the increase of fraud makes it worth the arrangement of this new specialty to improve its performance and to mitigate fraud. The literature discussed the requirements of forensic accounting using descriptive statistics to raise the basic needed to enrich this specialty and improve its performance. This research makes new contribution through discussing the different contributions required to improve fraud detection using forensic accounting. To figure out the effect of different forensic accounting aspects, a sample of wide range of accountants were taken (630). The accountants were asked to determine the extent of importance for different practices to improve forensic accounting and its contribution in discovering fraud. 
Citation: Hamdan MW (2018) The Role of Forensic Accounting in Discovering Financial Fraud. Int J Account Res 6: 176. doi: 10.35248/2472-

\begin{tabular}{|c|c|c|c|c|c|}
\hline & Estimate & S.E. & C.R. & $\mathbf{P}$ & Label \\
\hline$R \leftarrow S$ & 0.251 & 0.059 & 4.277 & $* * *$ & par_14 \\
\hline $\mathrm{R} \leftarrow \mathrm{T}$ & 0.014 & 0.031 & 0.444 & 0.657 & par_15 \\
\hline$R \leftarrow B$ & 0.176 & 0.043 & 4.1 & $\star \star *$ & par_16 \\
\hline $\mathrm{R} \leftarrow \mathrm{A}$ & 0.352 & 0.069 & 5.105 & $\star * *$ & par_17 \\
\hline$S 3 \leftarrow S$ & 0.842 & 0.045 & 18.555 & $\star \star *$ & par_1 \\
\hline $\mathrm{S} 2 \leftarrow \mathrm{S}$ & 0.998 & 0.042 & 23.784 & $* * *$ & par_2 \\
\hline $\mathrm{S} 1 \leftarrow \mathrm{S}$ & 1 & & & & \\
\hline
\end{tabular}

Table 9: Regression Weights of CFA model.

Practicing forensic accounting requires different skills and requirements related to both fields accounting and legal knowledge. The knowledge of the assignments required to practice the forensic accounting took the first place to accomplish success in this field and discover fraud. Running investigations in fraud cases had the highest contribution in assignments required. The ability to run investigation will facilitate the forensic accountant to figure out the facts and responsibilities of fraud discovered. The second contribution was for finding the conflict areas and evidences required approve cases. This activity is very important for forensic accountant to approve fraud and charge persons. The lack of this experience will affect the capabilities of forensic accountant to reach the facts and help the jury to reach a decision. The ability of forensic accountant to relate all documentation and results together considered very important to reach integrated case investigation to approve facts.

The second factors that contributed in figuring out fraud were for the skills required in practicing forensic accounting. Three items only contributed in the final model. The highest effect was for the requirement of certification to practice forensic accounting (S2), then the contribution of S1 (basic accounting skills are very important to be a successful forensic accountant). The third contribution that helps discovering fraud was for the requirement of deep experience of financial statements analysis and interpretation of these results. The item contributed explains the importance of high preparation of forensic accountant to help him practicing this profession to positively affect fraud detection.

The contribution of background in legal work was in third place. Only two items contributed to the final model to help in fraud discovering. The highest contribution was for the knowledge of case procedures and evidence rules to handle forensic accounting. This knowledge will enrich the forensic accountant experience to perform the steps according to law without violating the rules followed legally in investigation. The second important requirement was for knowledge of civil procedures and evidence rules. The knowledge of civil law procedures will deepen the cooperation with court to handle investigations and fraud detection without law violation that can be used to raise skepticism of the correctness of forensic accounting procedures.

The least effect was for the tools and procedures used. This may resulted of the fact that the accountants considered that the practice of forensic accounting requires the ability of forensic account to use these tools to practice his job.

Finally, the results showed that forensic accounting is crucial and very important to help mitigate the fraud. The extent of the experience and the use of forensic accounting as a profession with certification.

\section{Conclusions}

The objective of this research is to investigate the effect of forensic accounting on discovering fraud. To accomplish this objective wide sample of accountants was used. The questionnaire was used as a tool to collect data. Four variables were used as a measure to apply forensic accounting as a tool to discover fraud. These variables are: forensic accounting assignments, background of legal work, tool and procedures applied and skills required to practice forensic accounting.

The results showed that practicing forensic accounting is an effective in discovering fraud. The practice of forensic accounting was related to different skills should be available to help in finding fraud. The result showed that certification of forensic accountant is important to find considerable qualifications to execute forensic accounting.

\section{References}

1. Okoye E, Alamobi N (2009) The Role of Forensic Accounting in Fraud Investigation and Litigation Support. The Nigerian Academic Forum 17: 39-44.

2. Weygandt JJ, Kimmel PD, Kieso ED (2012) Accounting principles, International Student Version, $10^{\text {th }}$ ed. John Wiley.

3. Omoniyi S (2004) The emerging role of forensic accounting. The Nigerian Accountant, pp: 43-44.

4. Hopwood WS, Leiner JJ, Young GR (2008) Forensic Accounting. New York: McGraw-Hill//rwin.

5. Rasmussen DG, Leauanae JL (2005) Expert Witness Qualiications and Selection. Journal of Financial Crime 12: 165-171.

6. Charles D, Farrell R, Ogilby S (2010) Characteristics and skills of the forensic accountant. AICPA, FVS Section.

7. Wells JT (2003) The Fraud Examiners. Journal of Accountancy 196: 76-80.

8. Crumbley DL, Smith GS, Apostolou NG (2007) A Broad Approach to Forensic Accounting is Needed, The Value Examiner, pp: 13-19.

9. Crumbley DL, Heitger LE, Smith GS (2007) Forensic and Investigative Accounting, 3rd ed. $\mathrm{CCH}$ : Chicago.

10. Sanchez MH, Trewin J (2004) A Forensic Accountant as an Expert Witness in a Criminal Prosecution. Journal of Forensic Accounting 5: 231-235.

11. Smith GS (2005) Computer Forensics: Helping to Achieve the Auditor's Fraud Mission? Journal of Forensic Accounting 6: 119-134.

12. Florida Atlantic University (2008) Forensic accounting Information.

13. Brooks RC, Riley RA, Thomas J (2005) Detecting and Preventing the Financing of Terrorist Activities: A Role for Government Accountants. The Journal of Governmental Financial Management 54: 12-18.

14. Ojaide $F(2000)$ Frauds detection and prevention: the case of pension accounts ICAN NEWS, pp: 8.

15. Association of Certiied Fraud Examiners (ACFE) (2008) Higher Education Initiative.

16.Business and Finance Week (2008) Association of Certiied Fraud Examiners; ACFE Report.

17. Curtis GE (2008) The Model Curriculum in Fraud and Forensic Accounting and Economic Crime Programs at Utica College. Issues in Accounting Education 23: $581-592$.

18. Durtschi C, Hillison W, Pacini C (2004) The Effective Use of Benford's Law to Assist in Detecting Fraud in Accounting Data. Journal of Forensic Accounting pp: 17-34. 
Citation: Hamdan MW (2018) The Role of Forensic Accounting in Discovering Financial Fraud. Int J Account Res 6: 176. doi: 10.35248/2472114X.18.6.176

Page 6 of 6

19. Levine S, Morris HJ, Curry A, Sobel R, Gilgoff D, et al. (2002) Careers to Count On, U.S. News and World Report 132: 46-49.

20. Newswiren PR (2008) Demand for Forensic CPAs Accelerates, AICPA Survey Shows, New York.

21. Rezaee Z, Crumbley DL, Elmore RC (2004) Forensic Accounting Education: A
Survey of Academicians and Practitioners, Advances in Accounting Education Teaching and Curriculum Innovations 6: 193-231.

22. Robert Half (2009) Salary Guide Accounting and Finance.

23. Solnik C (2008) Bad Times Bode Well for Forensic Accounting, Long Island Business News. 